\title{
Bauhinia forficata Link Shoot Regeneration: Histological Analysis of Organogenesis Pathway
}

\author{
Marcia O. Mello ${ }^{1 *}$, Murilo Melo ${ }^{1}$ and Beatriz Appezzato-da-Glória ${ }^{2}$ \\ ${ }^{I}$ Centro de Biotecnologia Agrícola (CEBTEC) - Dept. of Biological Science, ESALQ/USP, SP, Brazil; ${ }^{2}$ Dept. of \\ Biological Science, ESALQ/USP, SP, Brazil
}

\begin{abstract}
Plant regeneration was achieved from cells of callus induced from hypocotyl segments of Bauhinia forficata on half strength Murashige and Skoog culture medium supplemented with several concentrations of BAP. Within 40 days of culture shoot buds formation was observed on callus surface. Calli were then transferred to a same composition culture medium without plant growth regulator in order to induce shoot elongation. Histological studies indicated that in vitro plant regeneration in $\mathrm{B}$. forficata occurred through indirect organogenesis. Meristemoids consisting of small cells with dense cytoplasm and prominent nuclei were randomly distributed throughout the callus surface indicating early stages of shoot bud differentiation. Shoots developed de novo from superficial layers of cells and the pattern of shoot origin and development were very similar to those previously described for other leguminous species.
\end{abstract}

Key words: Tissue culture, organogenesis, anatomy

\section{INTRODUCTION}

Bauhinia forficata, a leguminous tree, is native to Asia but has adapted and grown very well in several regions of Brazil (Cruz, 1985). This species has important medicinal properties as it can be used to treat diabetes, reducing the urinary glycaemia. Despite of its medicinal importance, it has not been commercially cultivated since its propagation is negatively affected by the long time (10-12 month) taken between flowering and seed production (Lorenzi, 1992). The aspects mentioned above and the absence of ecological and genetic information give support to the development of rapid and efficient methods for Bauhinia multiplication through tissue culture.

Organogenesis has been reported for some leguminous tree species such as Dalbergia sissoo (Kumar et al., 1991), Acacia nilotica subsp. indica (Dewan et al., 1992), Parkinsonia aculeata (Mathur \& Mukunthakumar, 1992) and Sesbania grandifolia (Detrez et al., 1994). Although micropropagation and organogenesis have been reported for B. purpurea L. (Kumar, 1992), B. variegata (Mathur \& Mukunthakumar, 1992) and B. vahlii Wight and Arnott (Upreti \& Dhar, 1996), no report on shoot bud formation structures from tissue culture is available in the literature for Bauhinia species.

The aims of this work were to establish a protocol for in vitro plant regeneration from cells of $B$. forficata that could be used in plant propagation and transformation assays, and to histologically monitorate the events taking place during the plant regeneration process characterizing the type of morphogenic competent cells.

\section{MATERIALS AND METHODS}

\section{a) Tissue Culture}

Seeds obtained from $B$. forficata plants growing naturally on the field at the University of São Paulo Campus, Piracicaba-São Paulo were surface sterilized in $2.0 \%(\mathrm{v} / \mathrm{v})$ sodium hypochloride for 15 minutes followed by immersion for three minutes in $70 \%(\mathrm{v} / \mathrm{v})$ ethanol and three washes in sterile distilled water. They were germinated in vitro on half strength MS (Murashige \& Skoog, 1962) culture medium containing $4.0 \mathrm{mg} . \mathrm{L}^{-1}$ 6benzylaminopurine (BAP), 30 g.L. $\mathrm{L}^{-1}$ sucrose and 2.3 g.L. ${ }^{-1}$ Phytagel (Sigma).

\footnotetext{
* Author for correspondence
} 
Hypocotyl segment explants of one centimeter $m$ length excised from 60 days old $B$. forficata in vitro germinated plants were used to initiate callus culture. The explants were inoculated on half strength MS medium, containing 30 g. $\mathrm{L}^{-1}$ sucrose, 2.3 g. L $^{-1}$ Phytagel (Sigma) and supplemented with several concentrations of BAP $(0.0,1.0,2.0,3.0$, $4.0 \mathrm{mg} . \mathrm{L}^{-1}$ ). All culture media were adjusted to pH 5.7 with $\mathrm{NaOH}$ prior to autoclaving. The cultures were maintained at $25 \pm 2^{\circ} \mathrm{C}$, under a light of $30 \mu \mathrm{mol} \cdot \mathrm{m}^{-2} \cdot \mathrm{s}^{-1}$ provided by "Philips" cool white fluorescent tubes and a $16 \mathrm{~h}$ per day photoperiod. Plants and calli were subcultured every 4 weeks. After 60 days of culture, calli were transferred to a same culture medium without growth regulator and maintained under the same conditions for shoot regeneration. The experiments were carried out three times that consisted in five treatments (different concentrations of BAP) with 10 replicates of each.

\section{b) Histological Analysis}

Along the culture period, samples were periodically taken and fixed in Karnovsky solution (Karnovsky, 1965). The fixed material was dehydrated through an ethanol series and then infiltrated with glycol methacrylate resin (Reichert-Jung, Germany). For general histological analysis, serial sections of $3 \mu \mathrm{m}$ thick were cut out on microtome and were stained with toluidine blue O (Sakai, 1973) or with aniline blue black (Fisher, 1968) for total protein. All samples were examined and photographed with a Nikon (Labophot) microscope.

For electron microscope analysis, samples were fixed and dehydrated as described before, dried to the critical point, mounted on aluminum stubs and sputter-coated with 40-50nm of gold. Observations and micrographs were made with a Zeiss MEV DSM-940A scanning electron microscope at $10 \mathrm{Kv}$.

\section{RESULTS AND DISCUSSION}

\section{a) Tissue Culture}

Formation of friable light yellow callus could be seen on the surface of hypocotyl segments of all treatments containing BAP 12 days after inoculation. The best BAP concentration for callus induction was $3.0 \mathrm{mg} . \mathrm{L}^{-1}$. Formation of green areas could be observed on callus surface within
40 days of culture, mainly on callus induced with 2.0 and $4.0 \mathrm{mg} . \mathrm{L}^{-1} \mathrm{BAP}$, where $100 \%$ of the calli showed these formations. After 60 days, the green areas developed into shoot buds in a frequency of 5 to 6 buds/ $0.5 \mathrm{~g}$ of callus. Frequencies similar to this were observed by Rai \& Chandra (1988) in Dalbergia latifolia, Kumar (1992) in Bauhinia purpurea and Dewan et al. (1992) in Acacia nilotica.

The addition of the auxins 2,4-D (Carvalho, 1998) and IAA was tested in tissue culture of $B$. forficata alone and in combination with BAP with no improvement of the number of shoot buds observed (data not shown).

Addition of BAP into culture medium for seed germination improved cellular division process of the nodal segments used as explants. Similar results were obtained by Buising et al. (1994) and Thomé et al. (1995) with Glycine max. According to Mohamed et al. (1992) and Thomé et al. (1995), explant cells already in an active process of division contribute to increase adventitious bud induction on the explant.

Shoot buds formed were isolated and transferred to a same composition culture medium without plant growth regulator for elongation. It has been observed for various legumes that high concentration of cytokinin stimulated callus and subsequently shoot bud formation (Malik \& Saxena, 1992; Dorneles et al., 1994), increased their survival (Dorneles et al., 1994) but also inhibited shoot growth (Thomé et al. 1995). Other studies with legumes in vitro (Dewan et al., 1992; Mohamed et al., 1992; Murthy et al., 1996) have determined the need of cytokinin for shoot differentiation and bud multiplication. The percentage of buds elongating into shoot regenerants was $68.2 \%$ in this work, compared to values of 81 and $94 \%$ obtained by Murthy et al. (1996) with Cicer arietinum.

The choice of MS culture medium to establish a protocol for B. forficata in vitro plant regeneration was due to its frequent use and good success for shoot induction in tissue culture studies of legumes trees like Swartzia madagascariensis (Berger \& Schaffner, 1995) and other species of Bauhinia genus (Upreti \& Dhar, 1996). The results obtained for MS culture

medium in half concentration showed no significant differences compared to the normal MS formulation. 


\section{b) Histological Analysis}

Hypocotyl of B. forficata anatomy used as explant in this work is shown in Figure 1. It was characterized by an unisseriate epidermis without hair. The cortex showed seven to eight layers of parenchyma cells, which presented smaller cells within the three inner layers. The vascular cylinder showed a continuous open collateral type with some sieve and tracheary elements already differentiated (Figure 1). Isodiametric parenchyma cells with intercellular space formed the pith.
The initial explant alterations could be detected after one week on MS culture medium (Figure 2). Some cortex and pith parenchyma cells dedifferentiated and underwent division. Anticlinal and periclinal divisions of the sub-epidermic layers, as well as hypertrophy and hyperplasy of others cortical parenchyma cells (Figure 3 ) lead to the enlargement of the cortex diameter and epidermis breaking. In the vascular cylinder, the number of cell layers in the procambial strand increased due to the periclinal divisions of the procambium and its derived cells.

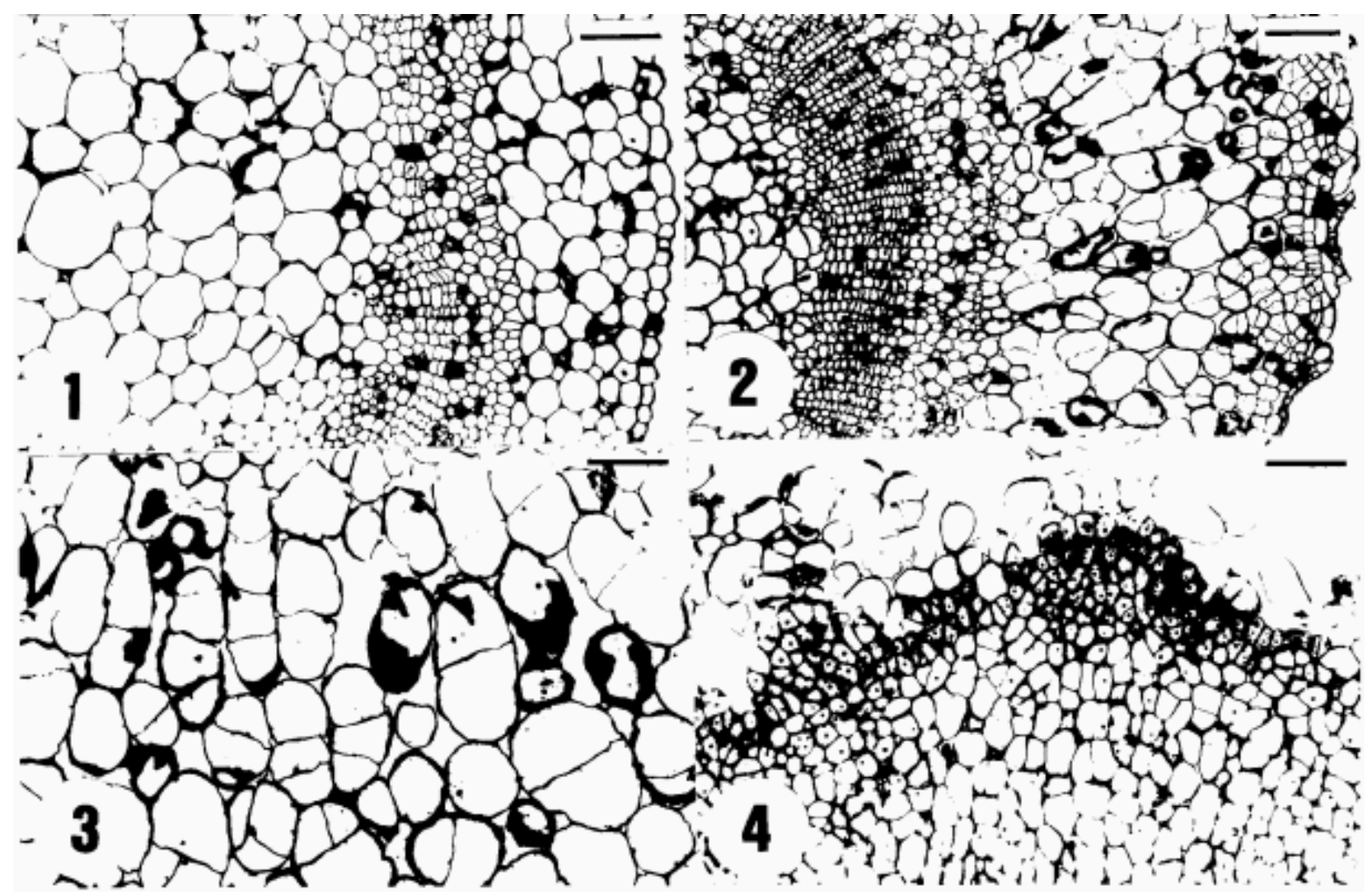

Figure 1 to 4. Transversal sections of the Bauhinia forficata hypocotyl used as explant. 1: at the inoculation time. 2: after one week at MS/2+4.0 mg.L $\mathrm{L}^{-1}$ BAP. 3: detail of the hypertrophy and hyperplasy of the cortical parenchyma cells. 4: after 12 days showing some meristematic areas on callus surface.

These divisions intensified during the culture time and after twelve days of culture, callus could be seen on explant surface. At this time, meristematic areas showing small, cytoplasmically dense cells with enlarged nuclei and nucleolus could be observed (Figure 4). 

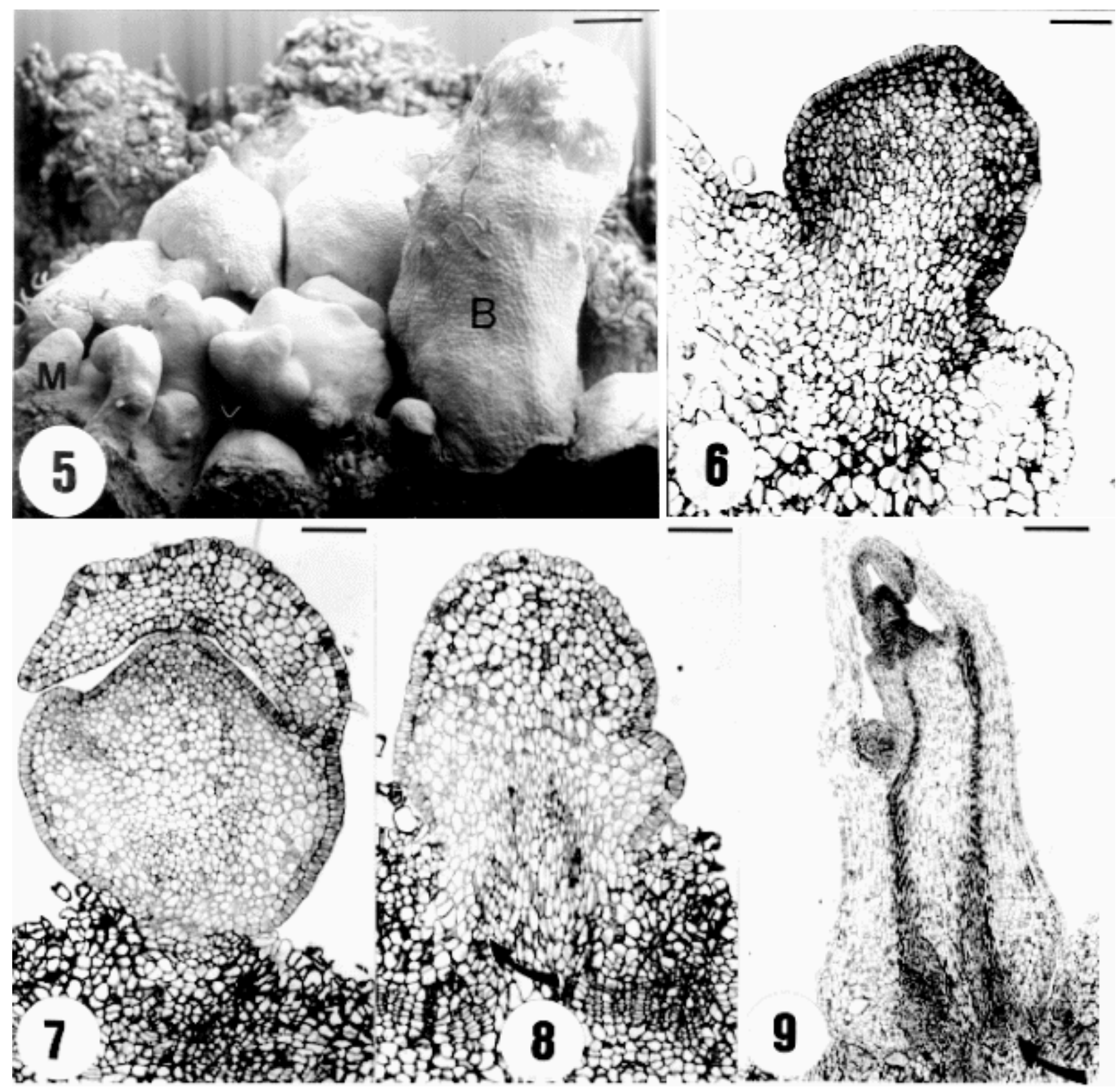

Figure 5 to 9. Bauhinia forficata callus after 42 days of culture. 5: electron micrography showing meristemoids (M) and shoot buds (B) at different stages of development. Longitudinal sections of the meristemoid (6) and shoot buds $(7,8,9)$ showing vascular connection with the cambium-like meristem on peripheral callus sectors (arrows).

A cambium-like meristem showing radial layers of small compact arranged cells, in which tracheary and sieve elements were differentiated could be observed along the periphery of the callus mass after 40 days of culture. Similar anatomy was observed for callus of Cichorium endivia and Petunia inflata by Vasil \& Hildebrandt (1966) and Handro et al. (1973), respectively. Several meristemoids and shoot buds in different stages of development could be observed on the same callus (Figure 5). Similar asynchrony was reported by Kelkar et al. (1996) in Piper colubrinum.
Meristemoids formation could be detected on the top of the meristematic area on some peripheral callus sectors (Figure 6). They were constituted of densely cytoplasmic small cells with prominent, enlarged nuclei. These were also observed by Kelkar et al. (1996) in Piper colubrinum. Those meristemoids elongated and acquired a welldefined shoot primordia shape (Figures 7-9) by undergoing several divisions. The indirect formation of shoot buds from meristematic areas on callus surface has also been reported for other 
species (Roussy et al., 1996; Kelkar et al., 1996) under diverse culture conditions.

In Bauhinia forficata, the expanded buds (Figure 9) were morphologically normal and present vascular connection with the callus (Figures 8 and 9). This connection is always established by the cambium-like meristem (Figure 8). According to Haccius (1978), these characteristics of a monopolar structure with wide vascular connection allowed the conclusion that the regeneration process was through organogenesis pathway.

\section{ACKNOLEDGMENTS}

We thank Mrs. Marli K. M. Soares for her excellent technical assistance, Dr. Elliot W. Kitajima from the "Centro de Microscopia Eletrônica" of the "Escola Superior de Agricultura Luiz de Queiroz" for facilities in the electron microscope analysis. We also thank $\mathrm{CNPq}$ and FAPESP for providing financial support for this project.

\section{RESUMO}

A regeneração de plantas de Bauhinia forficata a partir de calos induzidos em segmentos de hipocótilo foi obtida em meio de cultura contendo metade da formulação de sais de Murashige \& Skoog, suplementado com várias concentrações de BAP. Após 40 dias de cultura, ocorreu a formação de gemas adventícias na superfície do calo. Os calos que apresentavam tais formações, foram então transferidos para o mesmo meio de cultura mas sem a adição de fitorreguladores, visando o alongamento das gemas. Estudos histológicos indicaram que a regeneração in vitro de plantas de $B$. forficata ocorre pela via organogenética. Meristemóides caracterizados por células pequenas, de citoplasma denso e núcleo e nucléolo proeminentes se encontravam distribuídos pela superfície do calo, caracterizando os estágios iniciais da diferenciação de gemas caulinares. Partes aéreas se desenvolveram de novo a partir de camadas superficiais de células e seu padrão de origem e desenvolvimento foi muito similar aos previamente descritos na literatura para outras espécies de leguminosas.

\section{REFERENCES}

Berger, K.; Schaffner, W. (1995), In vitro propagation of the leguminous tree Swartzia madagascariensis. Plant Cell Tiss. Org. Cult., 40: 289-291

Buising, C.M.; Schoemaker, R.C.; Benbow, R.M. (1994), Early events of multiple bud formation and shoot development in soybean embryonic axes treated with the cytokinin, 6-benzylaminopurine. Amer. J. Bot., 81: 1435-1448

Carvalho, R.N. (1998), Cultivo in vitro de Bauhinia forficata Link. MS Thesis, University of São Paulo, Piracicaba, Brazil

Cruz, G.L. (1985), Dicionário de plantas úteis do Brasil. Civilização Brasileira, Rio de Janeiro

Detrez, C.; Ndiaye, S.; Dreyfus, B. (1994), In vitro regeneration of the tropical multipurpose leguminous tree Sesbania Grandiflora from cotyledon explants. Plant Cell Rep. 14: 87-93

Dewan, A.; Nanda, K.; Gupta, S.C. (1992), In vitro micropropagation of Acacia nilotica subsp. indica Brenan via cotyledonary nodes. Plant Cell Rep., 12: 18-21

Dorneles L.T.; Oliveira, A.C. de; Siebeneichler, S.C. (1994), Regeneração de plantas de feijão (Phaseolus vulgaris) via organogênese. Ciência Rural, 24: 287290

Fisher, D.B. (1968), Protein staining of ribboned epon sctions for light microscopy. Histochemie, 16: 92-96

Haccius, B. (1978), Question of unicellular origin of non-zygotic embryos in callus cultures. Phytomorphology, 28: 74-81

Handro, W.; Rao, P.S.; Harada, H. (1973), A histological study of the development of buds, roots and embryos in organ cultures of Petunia inflata R. Fries. Ann. Bot., 37: 817-821

Karnovsky, M.J. (1965), A formaldehydeglutaraldehyde fixative of high osmolality for use in electron microscopy. J. Cell Biol., 27: 137-138

Kelkar, S.M.; Deboo, G.B.; Krishnamurthy, K.V. (1996), In vitro regeneration from leaf callus in Piper colubrinum Link. Plant Cell Rep., 16: 215-218

Kumar, A. (1992), Micropropagation of a mature leguminous tree - Bauhinia purpurea. Plant Cell Tiss.Org. Cult., 31: 257-259

Kumar, A.; Tandon, P.; Sharma, A. (1991), Morphogenetic responses of cultured cells of cambial origin of a mature tree-Dalbergia sissoo Roxb. Plant Cell Rep., 9: 703-706

Lorenzi, H. (1992), Árvores brasileiras: manual de identificação e cultivo de plantas arbóreas nativas do Brasil. Plantarum, Nova Odessa

Malik, K.A.; Saxena, P.K. (1992), Somatic embryogenesis and shoot regeneration from intact seedlings of Phaseolus acutifolius A., P. aureus (L.) 
Wilczek, P. coccineus L., and P. wrightii L. Plant Cell Rep., 1: 163-168

Mathur, J.; Mukunthakumar, S. (1992), Micropropagation of Bauhinia variegata and Parkinsonia aculeata from nodal explants of mature trees. Plant Cell Tiss. Org. Cult., 28: 119-121

Mohamed, M.F.; Read, P.E.; Coyne, D.P. (1992), Dark preconditioning, CPPU, and Thidiazuron promote shoot organogenesis on seedling node explants of common and faba beans. Journal of the American Society for Hort. Sci., 117: 668-672

Murashige, T.; Skoog, F. (1962), A revised medium for rapid growth and bioassays with tobacco tissue cultures. Physiol. Plant., 15: 473-497

Murthy, B.N.S.; Victor, J.; Singh, R.P.; Fletcher, R.A.; Saxena, P.K. (1996), In vitro regeneration of chickpea (Cicer arietinum L.): stimulation of direct organogenesis and somatic embryogenesis by thidiazuron. Plant Growth Regulation. 19: 233-240

Rai, V.R.; Chandra, K.S.J. (1988), In vitro regeneration of plantlets from shoot callus of mature trees of Dalbergia latifolia. Plant Cell Tiss. Org. Cult., 13: 77-83

Roussy, I.; Frédéric, D.; Sangwan, R.S.; SangwanNorreel, B.S. (1996), In planta 2,3,5 triiodobenzoic acid treatment promotes high frequency and routine in vitro regeneration of sugarbeet (Beta vulgaris L.) plants. Plant Cell Rep., 16: 142-146

Sakai, W.S. (1973), Simple method for differential staining of parafilm embeded plant material using toluidine blue O1. Stain Techonol., 48: 247-249

Thomé, G.C.H.; Santarém, E.R.; Ferreira, A.G. (1995), Adventitious bud induction and plant regeneration from soybean cotyledonary nodes. Phyton, 57: 127135

Upreti, J. ; Dhar, U. (1996), Micropropagation of Bauhinia vahlii Wight \& Arnott - a leguminous liana. Plant Cell Rep., 16: 250-254

Vasil, I.K.; Hildebrandt, A.C. (1966), Variations of morphogenetic behavior in plant tissue cultures: I. Cichorium endivia. Amer. J. Bot., 53: 860-869.

Received: September 29, 1999; Revised: January 24, 1999; Accepted: April 07, 2000. 